\title{
Oidiodendron maius and Scytalidium vaccinii from the mycorrhizas of Ericaceae in northern Finland
}

\author{
RANDOLPH S. CURRAH, MARI NIEMI AND SEPPO HUHTINEN
}

\begin{abstract}
R. S. CURRAH, M. NIEMI \& S. HUHTINEN 1999: Oidiodendron maius and Scytalidium vaccinii from the mycorrhizas of Ericaceae in northern Finland. - Karstenia 39:65-68. Helsinki. ISSN 0453-3402
\end{abstract}

Scytalidium vaccinii was isolated from roots of Vaccinium vitis-idaea and Oidioden-
dron maius was isolated from roots of Vaccinium vitis-idaea, V. myrtillus, and Em-
petrum nigrum, all of which were collected on a fjell at Kevo Subarctic Research
Station in northern Finland. Both fungal species are mycobionts in ericoid mycor-
rhizas. These reports extend the known range of the common endomycorrhizal fungi
and indicate that these taxa have a circumboreal distribution with ericaceous plants.

Key words: Ericoid mycorrhizas, Myxotrichaceae, Hymenoscyphus ericae

R. S. Currah, Department of Biological Sciences, University of Alberta, Edmonton, Alberta, T6G 2E9, Canada

M. Niemi and Seppo Huhtinen, Herbarium, Centre for Biodiversity, University of Turku, FIN-20014 Turku, Finland

\section{Introduction}

Darkly-pigmented fungi, including Scytalidium vaccinii Dalpé, Sigler \& Litten (= anamorph state of Hymenoscyphus ericae (Read) Korf \& Kernan) and Oidiodendron maius Barron, form endomycorrhizas with many plants belonging to the Ericales. These fungi are, at least partially, responsible for the ability of the ericoid shrubs to survive and thrive in stressful habitats such as sand dunes, bogs, and alpine heaths (Read 1991). Although many of the ericaceous plant hosts have a circumboreal distribution, there are only a few localized reports concerning the identity of their mycorrhiza-forming fungi. H. ericae has been reported with Ericaceae and Epacridaceae worldwide (Egger and Sigler 1993, Straker 1996, Hambleton and Currah 1997, Chambers et al. 1999) whereas Oidiodendron maius has been reported primarily from western Canada, Britain, and Italy (Hambleton 1998, Stoyke and Currah
1991, Douglas et al. 1989, Perotto et al. 1994, 1996). There are no such reports of either mycorrhizal endophyte for the ericaceous plants of Finland.

\section{Materials and Methods}

In July 1998, plants of Vaccinium vitis-idaea L., Vaccinium myrtillus L., and Empetrum nigrum L. were collected at Kevo Subarctic Research Station in Kevo, Utsjoki, Finland ( $69^{\circ} 45^{\prime} \mathrm{N}, 27^{\circ} \mathrm{E} ; 80$ $\mathrm{m}$ asl). Plants were dug from the slope of Jesnalvaara Fjell which is dominated by Betula pubescens var. tortuosa with an understorey of primarily Vaccinium, Ledum and Empetrum shrubs.

Portions of the feeder roots were cut away, surface sterilized in approximately $10 \%$ household bleach for three minutes and rinsed several times in sterile distilled water and plated out on Corn Meal Agar (CMA) with tetracycline. Strains 
were transferred to and maintained on CMA for identification.

Fresh mounts in lactofuchsin were made for initial identifications. Cereal slide cultures (Sigler 1993) were prepared and mounted in acid fuschin-polyvinyl alcohol for taking photographs.

\section{Results and Discussion}

Both Oidiodendron maius and Scytalidium vaccinii were obtained in culture from the ericaceous species collected in Kevo. These ericoid mycorrhizal taxa are easily identified on the basis of the distinctive morphology of their arthroconidal states.

Oidiodendron maius forms a white or pale grey capitulum of mostly cylindrical arthroconidia which develop along a series of sinuous hyphae that emanate from the apex of a long (200$500 \mu \mathrm{m})$ thick-walled, dematiaceous conidiophore (Fig. 1). These dendritic structures, which

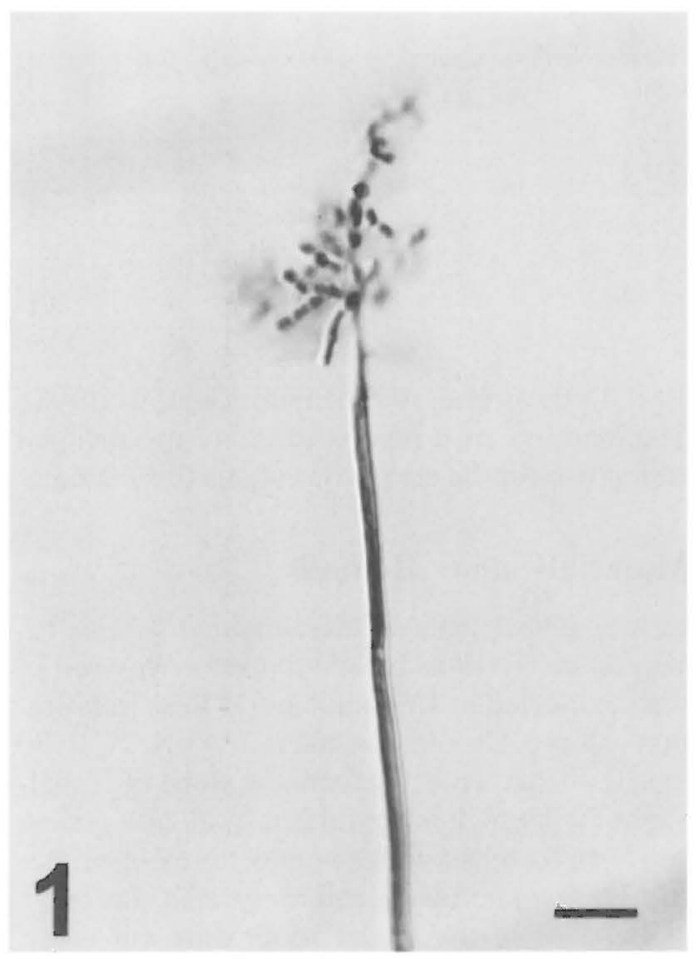

Figure 1. Capitulum of cylindrical arthroconidia of Oidiodendron maius (from Vaccinium myrtillus, Jesnalvaara Fjell) at the apex of a thick-walled, dematiaceous conidiophore. $\mathrm{Bar}=10 \mu \mathrm{m}$. are characteristic for the genus, form readily in culture. Hambleton and Currah (1997) point out that $O$. maius may be confused with $O$. griseum Robak which is probably a rhizosphere or soilinhabiting fungus rather than an ericoid mycorrhizal endophyte. Conidiophores of $O$. griseum are generally shorter $(<150 \mu \mathrm{m})$; the conidia are greyish to pale brown and develop in short compact chains. $O$. griseum also produces an ambercoloured diffusing pigment in agar media while no diffusing pigment is produced by $O$. maius. Molecular data show that, in spite of their superficial morphological similarity, these two taxa are not closely related within the genus (Hambleton, Egger and Currah 1998). Other species of Oidiodendron which may be found in organic soils e.g., O. periconioides Morrall (Currah, Tsuneda and Murakami 1993) are easily distinguished from $O$. maius on the basis of arthroconidial shape and size (Tokumasu 1973).

Within the Ericaceae, O. maius shows no detectable host specificity and has been identified

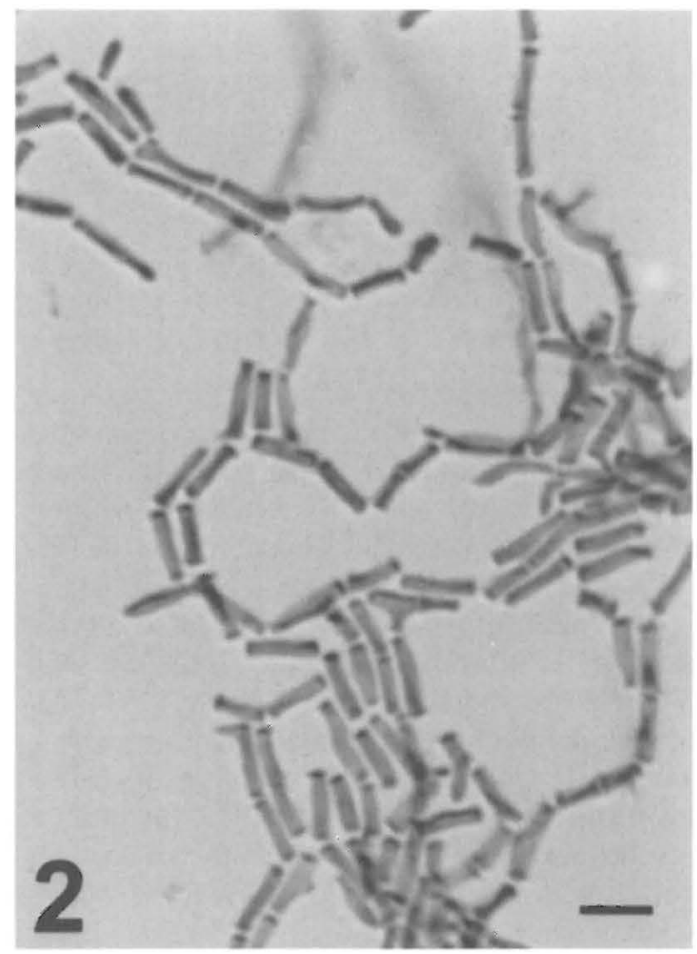

Figure 2. Distinctive zig-zag chains of long arthroconidia of Scytalidium vaccinii (from Vaccinium vitis-idaea, Jesnalvaara Fjell). Bar $=10 \mu \mathrm{m}$. 
from roots of many ericaceous plants from alpine and boreal regions of western Canada (Hambleton 1998), from Rhododendron grown in field culture in Ireland (Douglas et al. 1989), and from ericoid shrubs in Italy (Perotto et al. 1994, 1996). Our cultures were isolated from each of the three species: Vaccinium vitis-idaea, V. myrtillus, and Empetrum nigrum.

In Scytalidium vaccinii, morphology varies but, in general, colonies are slow growing and after two months are radially sulcate and creamy to more or less dematiaceous but retain some whitish aerial hyphae. However, on a relatively nutrient poor medium, e.g. CMA, the distinctive zig-zag chains of long, narrow $(1.5-2.5 \mu \mathrm{m}) \mathrm{ar}-$ throconidia form in abundance along prostrate hyphae (Fig. 2) and are diagnostic (Hambleton and Currah 1998). Our single strain was from Vaccinium vitis-idaea.

Both Oidiodendron maius and Scytalidium vaccinii are mitosporic states (Hyphomycetes) although the link between $S$. vaccinii and the teleomorph Hymenoscyphus ericae is now wellestablished on the basis of both molecular (Egger and Sigler 1993, Dalpé et al. 1989) and cultural and morphological evidence (Hambleton 1998, Hambleton et al. 1998). The taxonomic position of $O$. maius has been established among the inoperculates on the basis of the molecular similarity of $O$. maius, other species of Oidiodendron, and related teleomorphs in the Myxotrichaceae.

The distribution of $H$. ericae is probably global, being found wherever the Ericaceae or Epacridaceae (Ericales) occur (Egger and Sigler 1993, Hambleton and Currah 1997, Chambers et al. 1999, Straker 1996). The species has also been implicated in the formation of mycorrhizas in Pinaceae (Vrålstad and Schumacher 1998) or mycorrhiza-like structures in liverworts (Chambers et al. 1999) in habitats where these species occur concurrently with ericaceous shrubs. It is plausible that ericaceous plants and non-ericaceous neighbouring species are linked by these common mycorrhizal symbionts in much the same way as ectotrophic species (Simard et al. 1997). Consequently, the ecology of these associations would be of importance in cold- and nutrientstressed environments such as the fjell in Finland where our material was collected. Although an attempt was made, the fungi were not isolated from the roots of the neighbouring birch species.
These reports expand the known range of two known endomycorrhizal endophytes of the Ericaceae and indicate that these taxa have at least a circumboreal distribution with their host plants.

Acknowledgments. We thank Dr. Seppo Neuvonen for providing laboratory facilities and permission to collect specimens at Kevo Subarctic Research Station. The authors also thank Pia Vaininen, Piippa Wäli and Ann Smreciu for technical assistance. This work was supported in part by a grant to RSC from the Natural Sciences and Engineering Research Council of Canada.

\section{References}

Chambers, S.M., Williams, P.G., Seppelt, R.D. \& Cairney, J.G.W. 1999: Molecular identification of Hymenoscyphus sp. from rhizoids of leafy liverwort Cephaloziella exiliflora in Australia and Antarctica. Mycol. Res. 103: 286-288.

Currah, R.S., Tsuneda, A. \& Murakami S. 1993: Conidiogenesis in Oidiodendron ericonoides and ultrastructure of ericoid mycorrhizas formed with Rhododendron brachycarpum. - Can. J. Bot. 71:1481-1485.

Dalpé, Y., Litten, W. \& Sigler, L. 1989: Scytalidium vaccinii sp. nov., an ericoid endophyte of Vaccinium angustifolium roots. - Mycotaxon 35: 371-377.

Douglas G.C., Heslin, M.C. \& Reid, C. 1989: Isolation of Oidiodendron maius from Rhododendron and ultrastructural characterization of synthesized mycorrhizas. - Can. J. Bot. 67: 2206-2212.

Egger, K.N. \& Sigler, L. 1993: Relatedness of the ericoid endophytes Scytalidium vaccinii and Hymenoscyphus ericae inferred from analysis of ribosomal DNA. Mycologia 85: 219-230.

Hambleton, S. 1998: Mycorrhizas of the Ericaceae: Diversity and Systematics of the mycobionts. Ph.D. Thesis. - Department of Biological Sciences, University of Alberta. Edmonton, Alberta. 145 pp.

Hambleton, S. \& Currah, R.S. 1997: Fungal endophytes from the roots of alpine and boreal Ericaceae. - Can. J. Bot. 75: 1570-1581.

Hambleton, S., Egger, K. N. \& Currah, R. S. 1998: The genus Oidiodendron: species delimitation and phylogenetic relationships based on nuclear ribosomal DNA analysis. - Mycologia 90:854-869.

Hambleton, S., Huhtinen, S. \& Currah, R.S. 1999: Hymenoscyphus ericae: new record from western Canada. - Mycol. Res. 103: in press.

Perotto, S., Actis-Perino, E., \& Bonfante, P. 1994: Fungal diversity within ericoid mycorrhizal roots analysed with PCR-RAPD techniques. - In: Daniel, M.J. (ed.), Advances in Molecular Genetic of Plant-Microbe Interactions. Proceedings of the 7th International Symposium of Molecular Plant-Microbe Interactions, Edinburgh, Scotland, 26 June-July 1, 1994. Vol. 3: 187-190. Kluwer Press, New York. 
Perotto, S., Actis-Perino, E., Perugini, J., \& Bonfante, P A. 1996: Molecular diversity of fungi from ericoid mycorrhizal roots. - Mol. Ecol. 5: 123-131.

Read, D. J. 1991: Mycorrhizas in ecosystems. - Experientia 47: 376-391.

Sigler, L. 1993: Preparing and mounting slide cultures. In: Isenderg, H.D. (ed.), Clinical microbiology handbook. American Association for Microbiology, Washington, D.C. pp. 6.12.1-6.12.4.

Simard, S.W., Perry, D.A., Jones, M.D., Myrolds, D.D., Durall, D.M, \& Molina, R. 1997: Net transfer of carbon between ectomycorrhizal tree species in the field. - Nature 388: 579-582.
Stoyke, G. \& Currah, R.S. 1991: Endophytic fungi from the mycorrhizae of alpine ericoid plants. - Can. J. Bot. 69: 347-352.

Straker, C.J. 1996: Ericoid mycorrhiza: ecological and host specificity. - Mycorrhiza 6: 215-225.

Tokumasu, S. 1973: Notes on Japanese Oidiodendron (Japanese microscopic fungi II). - Trans. Mycol. Soc. Japan 14:246-255.

Vrålstad, T. \& Schumacher, T. 1998: Post-fire recolonization of ectomycorrhizal Ascomycetes on natural rejuvenated seedlings of Scottish pine (Pinus sylvestris) and Norway spruce (Picea abies). - In: Programme and Abstracts of the Second International Conference on Mycorrhiza, Uppsala, Sweden.

Received on 30 August 1999 